\title{
Non-isotopic in situ hybridisation and immunophenotyping of infected cells in the investigation of human fetal parvovirus infection
}

\author{
A L Morey, H J Porter, J W Keeling, K A Fleming
}

\begin{abstract}
Aims: To compare the use of biotinylated and digoxigenin labelled probes for diagnosis of human fetal parvovirus B19 infection in formalin fixed, paraffin wax embedded tissues; and to assess the cellular distribution of the virus in positive cases.

Methods: Sections of lung tissue from 23 cases of anatomically normal nonimmune fetal hydrops presenting between 1984 and 1989, and from 13 control cases of hydrops due to chromosomal abnormality were probed for B19 DNA by in situ hybridisation using both biotinylated and digoxigenin labelled probes. The distribution of the virus was then investigated in all cases of fetal B19 infection confirmed in this laboratory to date $(n=11)$ by combining in situ hybridisation for viral DNA (using the digoxigenin system) with immunohistological labelling for a range of cellular antigens.
\end{abstract}

Results: Five unequivocal cases of B19 infection were identified among the 23 fetuses with unexplained hydrops using both probe labels. When combined with data from previous studies of the period 1974-1983, the results indicate that B19 infection was responsible for $27 \%$ of cases of anatomically normal non-immune hydrops and $8 \%$ of all cases, of nonimmune hydrops presenting to this hospital over 15 years. False positive signal was seen in an additional three cases, using biotinylated probes. Digoxigenin labelled probes gave greater specificity and permitted detailed investigation of tissues high in endogenous biotin. Though most cells containing B19 DNA colabelled as erythroid precursors, viral DNA was frequently detected within mononuclearphagocytic cells. In three cases viral signal was also found within occasional myocardial cells labelled by antibody to desmin.

University of Oxford, Nuffield Department of Pathology and Bacteriology, John Radcliffe Hospital, Oxford OX3 9DU AL Morey HJ Porter

JW Keeling,

KA Fleming

Correspondence to:

Dr AL Morey

Accepted for publication 31 January 1992
Conclusions: A relatively high proportion of cases of anatomically normal, nonimmune hydrops are caused by $B 19$ infection. Digoxigenin is a more reliable probe label than biotin for in situ hybridisation in archival fetal tissues. Double labelling for cellular antigens and viral nucleic acid is a powerful technique for investigating virus-host cell interactions, and provides evidence that cell types other than those of erythroid lineage may have a role in human fetal parvovirus infection.
Human parvovirus B19 was discovered in $1975^{1}$ and subsequently shown to be the cause of the common childhood illness erythema infectiosum or "fifth disease". " More importantly, the virus is capable of causing transient aplastic crises in patients with chronic haemolytic anaemias, ${ }^{3}$ prolonged bone marrow dysfunction in the immunosuppressed, ${ }^{4}$ and fetal death associated with hydrops. ${ }^{5}$ Fetuses infected in utero do not always produce a measurable IgM antibody response, ${ }^{6}$ and the virus's particular tropism for human erythroid precursors means that diagnosis cannot be made by culture in standard cell lines or animal models. Until very recently, ${ }^{7}$ there were no monoclonal antibodies to the virus which were effective on formalin fixed material, and detection of viral DNA within fetal blood or tissues is generally regarded as the most reliable way of diagnosing intrauterine infection.

A pilot study from this laboratory using nonisotopic in situ hybridisation with a biotinylated probe detected B19 DNA in formalin fixed, paraffin wax embedded lung tissue from four out of 13 cases of hydrops fetalis of unknown cause. ${ }^{8}$ The present study extends that investigation to a great number of cases and compares the use of biotinylated and digoxigenin labelled probes for retrospective diagnosis of B19 infection in archival tissues. The cell types involved were identified by sequential immunohistology and in situ hybridisation. Preliminary data on the use of this combined technique have been presented elsewhere. ${ }^{910}$

\section{Methods}

Formalin fixed, paraffin wax embedded lung tissue was obtained from 23 cases of nonimmune fetal hydrops presenting between 1984 and 1989 which could not be explained on the basis of chromosomal or anatomical abnormality. Gestational age ranged from 15 to 38 weeks. Histological features suggestive of viral infection were present in 11 cases, and plum-coloured intranuclear inclusions ${ }^{11}$ had been noted in three, raising suspicion of B19 infection. As controls, sections of lung tissue from all available cases of hydrops with confirmed chromosomal abnormality presenting over the same period were tested in parallel (14 cases: 15-23 weeks' gestation). Placental tissue from a hydropic fetus shown to be infected by B19 by dot-hybridisation studies ${ }^{5}$ was used as a positive control in each batch of sections tested.

Sections $(5 \mu \mathrm{m})$ were cut on to slides coated 
with $1 \%$ 'silane in acetone. ${ }^{12}$ After dewaxing, proteolytic digestion was performed with proteinase $\mathrm{K}$ as previously described, ${ }^{13}$ the optimal strength and duration of proteolytic digestion varying for each block, depending on the degree of autolysis and length of fixation. Representative sections were exposed to DNAse I or heat treated RNAse A after proteolytic digestion, or both. ${ }^{12}$ Sections were denatured in autoclaved deionised water $\left(\mathrm{dH}_{2} \mathrm{O}\right)$ at $95^{\circ} \mathrm{C}$ for 10 minutes, cooled rapidly in ice-cold $\mathrm{dH}_{2} \mathrm{O}$, and air dried.

Plasmids pYT 104 (containing $95 \%$ of the $\mathrm{B} 19$ genome in a riboprobe vector ${ }^{14}$ ), $\mathrm{pBR} 322$ without insert, and $\mathrm{pHY} 2 \cdot 1$ (containing a $2 \cdot 1$ kilobase $\mathrm{Y}$ chromosome repeat sequence ${ }^{15}$ ) were nick-translated with either biotin11-dUTP or digoxigenin-11-dUTP. ${ }^{12}$ Probes were added at a final concentration of $1 \mu \mathrm{g} / \mathrm{ml}$ to hybridisation mixture consisting of $10 \%$ dextran sulphate, $50 \%$ deionised formamide, $250 \mu \mathrm{g} / \mathrm{ml}$ sheared herring sperm DNA, 300 $\mathrm{mM} \mathrm{NaCl}, 60 \mathrm{mM}$ TRIS, $4 \mathrm{mM}$ EDTA (pH $7 \cdot 0$ ), then denatured at $95^{\circ} \mathrm{C}$ for 15 minutes and snap frozen. For each case, consecutive sections on one slide were incubated under sealed coverslips with biotinylated pYT104, pBR322 (negative control), and pHY2 1 (positive "technique" control) for two hours at $37^{\circ} \mathrm{C}$, and a duplicate experiment was performed using the same probes labelled with digoxigenin. Coverslips were removed by washing in TBS (15 mM TRIS, $0.15 \mathrm{M} \mathrm{NaCl}$, pH 7.2) with $0.5 \%$ Triton- $\mathrm{X} 100$ at $37^{\circ} \mathrm{C}$ and stringency washes performed in $0.5 \mathrm{xTBS}$ at $65^{\circ} \mathrm{C}$. Blocking was performed with $15 \%$ skimmed milk powder in AP7. 5 buffer $(0.1 \mathrm{M}$ TRIS, $0.1 \mathrm{M} \mathrm{NaCl}, 2 \mathrm{mM} \mathrm{MgCl}$, $\mathrm{pH} \mathrm{7.5)}$ with $0.5 \%$ Triton $\left(20\right.$ minutes at $37^{\circ} \mathrm{C}$ ) and bound probe detected with either avidinalkaline phosphatase conjugate (Dako; 1 in 250) or anti-digoxigenin-alkaline phosphatase conjugate (Boehringer Mannheim; 1 in 750) diluted in $2 \%$ bovine serum albumin in AP7.5/ $0.5 \%$ Triton $\left(30\right.$ minutes at $\left.37^{\circ} \mathrm{C}\right)$. Unbound conjugate was removed by thorough washing in AP7.5/0.5\% Triton and substrate buffer, then sections were immersed in NBT-BCIP substrate ${ }^{12}$ overnight. Successful detection of the 200 autosomal homologues of the $2 \cdot 1$ kilobase $Y$ repeat sequence (in addition to the 2000 copies on the $\mathrm{Y}$ chromosome ${ }^{15}$ ) was regarded as evidence that proteolytic digestion had been adequate.

The distribution of cells containing viral

Table 1 Antibodies used in double labelling experiments

\begin{tabular}{|c|c|c|c|}
\hline $\begin{array}{l}\text { Monoclonal } \\
\text { antibody }\end{array}$ & Antigen & Cell types labelled & $\begin{array}{l}\text { Digestion } \\
\text { required }\end{array}$ \\
\hline $\begin{array}{l}\text { JC } 159 \\
\text { Ret40f } \\
\text { PD7/26+2B11 } \\
\text { KP1 } \\
\text { EBM11 } \\
\text { MAC } 387 \\
\text { DF-T1 } \\
\text { F8/86 } \\
\text { MNF116+ LP34 } \\
\text { DE-R-11 }\end{array}$ & $\begin{array}{l}\text { Glycophorin A } \\
\text { Glycophorin C } \\
\text { CD45 (LCA) } \\
\text { CD68 } \\
\text { CD68 } \\
\text { (L-1 antigen) } \\
\text { CD43 (leucosialin) } \\
\text { von Willebrand factor } \\
\text { Cytokeratins } \\
\text { Desmin }\end{array}$ & $\begin{array}{l}\text { Erythrocytes and precursors } \\
\text { Erythrocytes and precursors } \\
\text { Most leucocytes } \\
\text { Activated macrophages } \\
\text { Macrophages } \\
\text { Granulocytes, monocytes, histiocytes } \\
\text { T cells, some B cells, and myeloid cells } \\
\text { Endothelial cells, megakaryocytes } \\
\text { Epithelial cells } \\
\text { Striated, cardiac, and smooth muscle }\end{array}$ & $\begin{array}{l}- \\
+ \\
- \\
++ \\
+\star \\
+ \\
+ \\
+ \\
+ \\
++\end{array}$ \\
\hline
\end{tabular}

All antibodies are available from Dako Ltd. They were selected on the basis of preliminar experiments which indicated they were effective on tissues which had undergone prolonged formalin fixation. ${ }^{\star}$ Digestion with protease XIV specifically required.
DNA was assessed in all available organs from 11 cases of B19 DNA positive fetal hydrops using digoxigenin labelled probe pYT104. Cases included those detected in the present study, four cases reported in a previous study, ${ }^{8}$ one case from the Oxfordshire region not previously reported, and one case from University College Hospital, London. The density of positive cells in each tissue was averaged over a minimum of 10 high power fields. Digoxigenin labelled plasmids pBR322 and pHY2.1 were used as negative and positive control probes, as described above.

Sequential immunohistology for cellular antigens and in situ hybridisation for B19 DNA were performed on a range of tissues from each case to identify the cell types involved. Monoclonal antibodies used for cell typing are shown in table 1 . Immunostaining was performed using the APAAP method ${ }^{16}$ with Fast Red as the substrate. Digestion with proteinase $\mathrm{K}$ gave satisfactory results with most antibodies requiring proteolytic pretreatment; the degree of digestion required for optimal immunolabelling also being sufficient for penetration of the parvovirus probe. A second digestion protocol using $1 \%$ protease type XIV (Sigma) in TBS at $24^{\circ} \mathrm{C}$ for $15-30$ minutes ${ }^{17}$ was also effective, with the unique advantage of enabling labelling with EBM11, an antibody to CD68 generally regarded as unreactive on paraffin wax embedded tissues.

\section{Results}

Five of the 23 cases of "unexplained" hydrops were shown to be unequivocally associated with B19 infection, using both biotinylated and digoxigenin labelled probes. All five cases presented in the years 1988-1989 in the second trimester of pregnancy. No cases of hydrops due to chromosomal abnormality had positive B19 signal with either probe label, but three cases of anatomically normal hydrops thought to be due to viral infection on the basis of routine histology repeatedly produced an equivocal result when tested with both biotinylated B19 probe and biotinylated pBR322. Reprobing with digoxigenin labelled probes resulted in a general decrease in background signal and loss of the "positive" signal, suggesting that it was non-specific and possibly due to the presence of relatively high concentrations of endogenous biotin in certain individual cells. While the strength of the Y-repeat signal evident with the digoxigenin system was slightly less than that seen with the avidinbiotin system after one hour in substrate, the signals were of equal strength after overnight incubation; thus final sensitivity was comparable. Based on the ability to detect the 200 autosomal homologues of the $2 \cdot 1$ kilobase Y-repeat sequence with both probe types, we estimate that the technique was capable of detecting less than 75 copies of the 5.6 kilobase B19 genome per cell.

The pYT104 hybridisation signal was relatively resistant to DNAse digestion, requiring DNAse concentrations up to $10 \mathrm{mg} / \mathrm{ml}$ for complete removal, while the $\mathrm{Y} 2 \cdot 1$ signal was 
Table 2 B19 DNA positive cells in each organ averaged over 10 high power fields (HPF)

\begin{tabular}{|c|c|c|c|c|c|c|c|c|c|c|c|}
\hline $\begin{array}{l}\text { Case No } \\
\text { Gestational age }\end{array}$ & $\begin{array}{l}1 \\
14 / 40\end{array}$ & $\begin{array}{l}2 \\
15 / 40\end{array}$ & $\begin{array}{l}3 \\
19 / 40\end{array}$ & $\begin{array}{l}4 \\
20 / 40\end{array}$ & $\begin{array}{l}5 \\
23 / 40\end{array}$ & $\begin{array}{l}6 \\
23 / 40\end{array}$ & $\begin{array}{l}7 \\
24 / 40\end{array}$ & $\begin{array}{l}8 \\
24 / 40\end{array}$ & $\begin{array}{l}9 \\
25 / 40\end{array}$ & $\begin{array}{l}10 \\
29 / 40\end{array}$ & $\begin{array}{l}11 \\
28 / 40\end{array}$ \\
\hline $\begin{array}{l}\text { Liver } \\
\text { Spleen } \\
\text { Lung } \\
\text { Pancreas } \\
\text { Rib marrow } \\
\text { Heart } \\
\text { Thymus } \\
\text { Kidney } \\
\text { Adrenal } \\
\text { Diaphragm } \\
\text { Gut } \\
\text { Brain } \\
\text { Placenta }\end{array}$ & $\begin{array}{l}2+ \\
2+ \\
2+\end{array}$ & $\begin{array}{l}2+ \\
2+ \\
3+ \\
2+ \\
2+ \\
2+\end{array}$ & $\begin{array}{l}5+ \\
4+\end{array}$ & $\begin{array}{l}+ \\
2+ \\
2+ \\
2+ \\
\\
+ \\
+1-\end{array}$ & $\begin{array}{l}4+ \\
3+ \\
3+ \\
\\
3+ \\
3+ \\
3+ \\
3+ \\
2+ \\
+ \\
2+\end{array}$ & $\begin{array}{l}5+ \\
4+ \\
4+ \\
3+ \\
\vdots \\
3+ \\
3+ \\
3+ \\
2+ \\
2+ \\
2+ \\
\\
2+\end{array}$ & $\begin{array}{l}5+ \\
5+ \\
4+\end{array}$ & $\begin{array}{l}3+ \\
5+\end{array}$ & $4+$ & $\begin{array}{l}5+ \\
4+ \\
3+ \\
\star \\
3+ \\
3+ \\
2+ \\
2+\end{array}$ & $\begin{array}{l}4+ \\
3+ \\
3+\end{array}$ \\
\hline
\end{tabular}

Tissues have been ranked according to B19 content

*Hybridisation signal absent though inclusions seen.

Key:

$+/-=$ less than 1 positive cell per $10 \mathrm{HPF}$

$+=\geq 0 \cdot 1$ but $<1$ positive cells $/ \mathrm{HPF}$

$2+=\geq 1$ but $<10$ positive cells/HPF

$3+=\geq 10$ but $<50$ positive cells/HPF

$4+=\geq 50$ but $<100$ positive cells/HPF

$5+=\geq 100$ positive cells/HPF

removed at one fiftieth of that concentration. The pYT104 signal was unaffected by RNAse treatment, suggesting that only B19 DNA was being detected by the protocol used.

Four of the five B19 DNA positive cases detected in this screening study had vast numbers of infected cells in each section. The sensitivity of the in situ hybridisation technique is shown by the reproducible detection of less than one positive cell per high power field in the fifth case. Typical inclusion containing cells were not readily visible on examination of haematoxylin and eosin stained sections of lung from this fetus, though B19 specific IgM was detected in the maternal serum.

Preliminary attempts to examine a broader range of fetal tissues infected with B19 using biotinylated probes were complicated by the high concentrations of endogenous biotin in organs such as the heart, liver, and kidney. Use of digoxigenin labelled probes, however, per-

Figure 1 Digoxigenin labelled $B 19$ probe on fetal lung (case 2). Positive hybridisation signal was associated with acellular material within blood vessels as well as with individual infected cells.

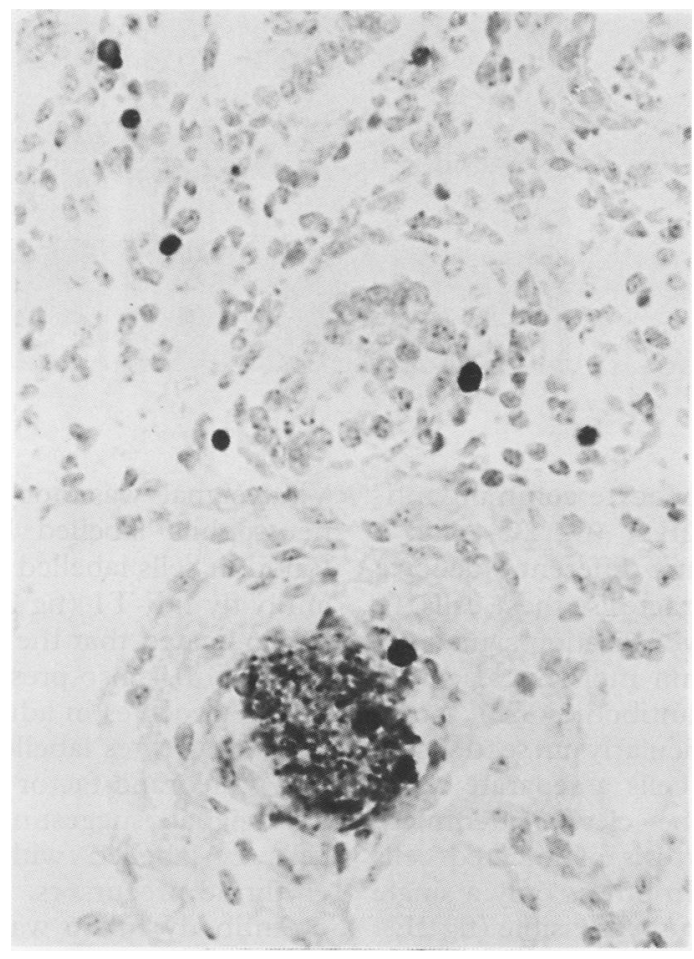

mitted accurate localisation of B19 DNA in all tissues with minimal background signal. The number and distribution of positive cells varied greatly from tissue to tissue and from case to case, though certain trends were observed (table 2). Many more cells contained viral DNA than contained typical inclusions on routine staining. Positive cells were frequently, though not exclusively, found within blood vessels and small capillaries. Positive debris as well as whole cells were commonly found within the liver and spleen. In all but one of the infected fetuses the liver contained the greatest number of positive cells. Viral DNA could readily be detected despite histological evidence of advanced autolysis. As previously noted, ${ }^{18}$ infected cells seem to be unusually resistant to degradation, possibly because of their high (viral) DNA content. Lung tissue generally contained moderate numbers of positive nuclei, many lying close to the alveolar margins. In the kidney, cells containing B19 DNA were mainly located within the glomerular capillaries, while in the thymus they were focally distributed at the periphery of lobules, unrelated to Hassall's corpuscles. Virus positive nuclei in the heart were evenly scattered across the myocardium, which in most cases was also quite severely autolysed. Most positive nuclei clearly lay within small capillaries, while some were more elongate in shape and seemed to lie within myocytes. Despite the presence of obvious viral inclusions in all three samples of bone marrow tested, hybridisation signal was only obtained in one; the loss of signal possibly representing an artefact of decalcification processing. Few positive cells were seen in the available blocks of brain tissue. Most seemed to be associated with blood vessels, though capillary walls were often indistinct. B19 hybridisation signal within the placenta was confined to the villi: the membranes and decidua being free of infected cells in all cases available for study. The number of infected cells seen in the placenta varied considerably between cases, and did not correlate with the amount of signal detected in other organs. In one fetus, the parvovirus probe hybridised strongly to acellular material within the lumen of large vessels (fig 1), suggesting that aggregates of "free" circulating virus can also be detected in routinely fixed, paraffin wax embedded tissues by in situ hybridisation if the viral titre is sufficiently high. No particular age related differences in the pattern of viral distribution were detected, and the intensity of labelling of positive cells did not vary appreciably between fetuses, though the total numbers of infected cells varied considerably from case to case.

The classic parvovirus inclusion containing cell was confirmed to be a late erythroid precursor by the use of antibody JC159 against glycophorin A (fig 2A). Most B19 DNA positive cells in each case colabelled unequivocally with anti-glycophorin antibodies JC159 and Ret40f, though many clearly did not (fig 2B). In some cases this may have been due to loss of antigen expression by infected cells, but a proportion of DNA positive cells were found 
Figure 2 (A) A typical inclusion containing cell with marginated chromatin labelled as an erythroid precursor (arrow) by antibody $\mathcal{F C 1 5 9}$ (fetal lung; case 7).

(Haematoxylin

counterstain.)

(B) Fetal lung (case 5) labelled with antibody Ret40f to glycophorin $C$ (Fast Red substrate) and digoxigenin-labelled B19 probe (purple/black substrate). Not all B19 DNA positive cells colabelled as erythroid precursors.

(C) Fetal lung (case 11) showing a cell colabelling with leucocyte common antibody and B19 probe. (D) Macrophage labelled with EBM11 containing both a B19 DNA positive cell and a separate uninfected nucleus (fetal liver: case 11).

(E) Monocyte/macrophage in the placenta (case 9) labelled by antibody KP1 with apparent single B19 DNA positive nucleus. (F) Colabelling of an infected cell at the periphery of a thymic lobule (case 10) with antibody $D F-T 1$.

(G) Labelling of

endothelium in brain (case 11) with antibody $F 8 / 86$ indicated that B19 DNA positive cells were limited to the microcirculation.

(H) Viral signal was not apparent in columar epithelium in the fetal lung labelled by anti-cytokeratin antibody combination MNF116/LP34 (case 11), though infected cells lay close to the alveolar margins.

(I) A B19 positive nucleus (arrow) within a myocardial cell colabelled with antibody DE-R-11 against desmin (case 7). Compare the typical infected cells lying in nearby capillaries.
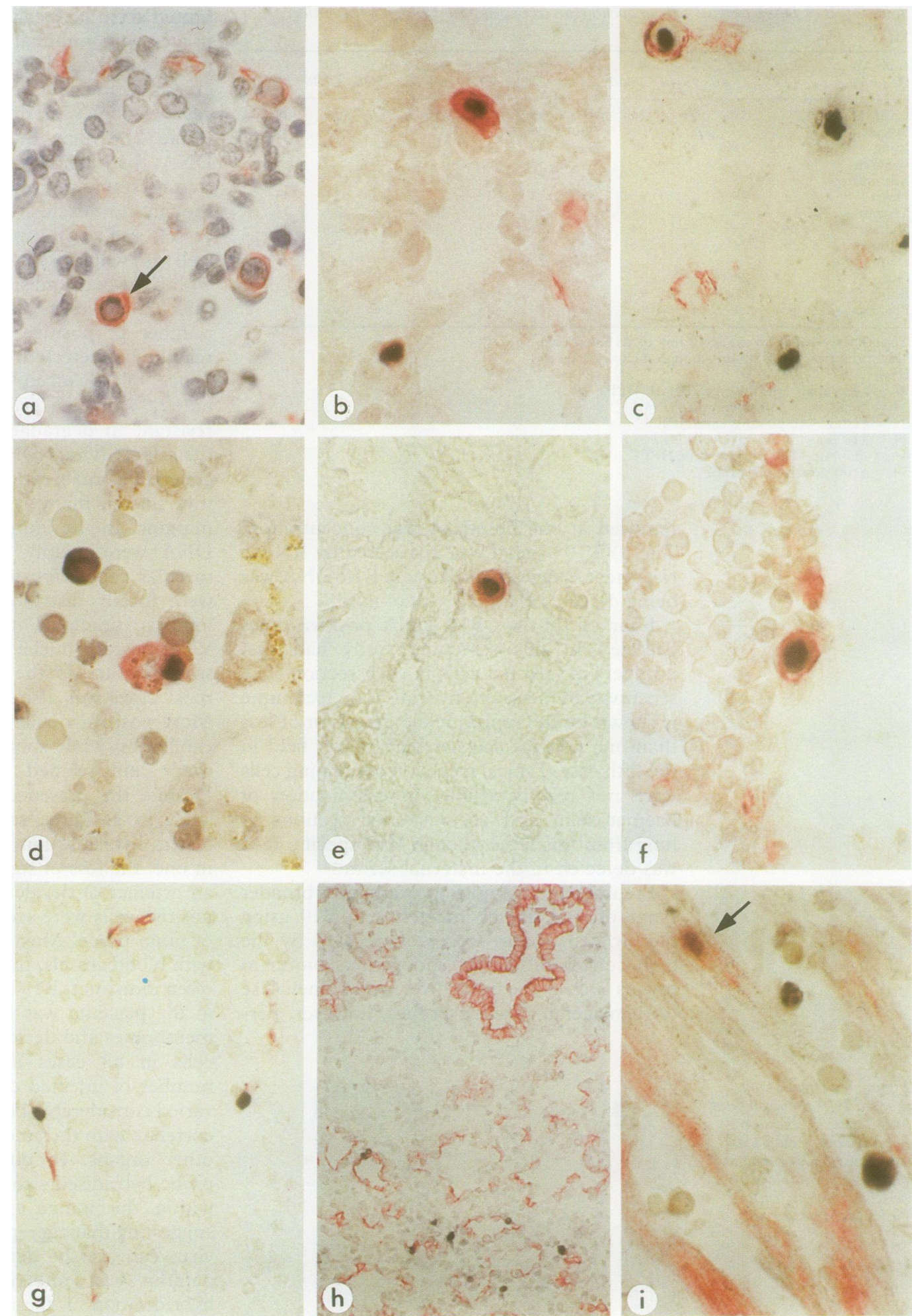

to label with the anti-leucocyte common antigen combination $\mathrm{PD} 7 / 2 \mathrm{~B} 11$ (fig 2C), and a range of antibodies against different leucocyte antigens was used to characterise these cells. In all 11 infected fetuses hybridisation signal was frequently detected within mononuclear-phagocytic cells labelled by antibodies KP1, MAC 387, and EBM11, particularly in sections of liver. In some of these cells a separate uninfected nucleus could be clearly identified, suggesting that phagocytosis of infected cells had occurred (fig 2D). In others only a single $\mathrm{B} 19$ DNA positive nucleus was visible (fig $2 \mathrm{E}$ ).
Viral signal was not detected in circulating neutrophils labelled by MAC 387 , but was found in cells labelled by the " $T$ cell/myeloid" antibody DF-T1 (fig $2 \mathrm{~F}$ ), though recent work has indicated that the CD43 antigen detected by DF-T1 is also present on normoblasts and megakaryocytes in adult bone marrow. ${ }^{19}$ Fetal megakaryocytes labelled by antibody F8/86 to von Willebrand factor did not contain obvious viral signal, suggesting that the B19 positive cells co-labelled with DF-T1 were indeed erythroid precursors.

Antibody F8/86 was also used to delineate 
the endothelial lining of capillaries, and confirmed that B19 DNA positive cells in the brain were confined to the microcirculation (fig $2 G$ ). Infection of endothelial cells was not conclusively shown in any tissue, though the presence of positive material within blood vessels (fig 1) occasionally made interpretation difficult. Double labelling with the anti-cytokeratin combination MNF116/LP43 showed that although B19 is thought to be spread by the respiratory route in the community, B19 DNA was not present in the columnar epithelial cells lining large airways (fig $2 \mathrm{H}$ ), though many positive nuclei lay directly beneath the alveolar margins. Double labelling with the same anti-cytokeratin combination in renal and intestinal tissue confirmed that there was no viral signal within either the tubular epithelium of the kidney or the gut epithelium. Within non-autolysed myocardium available from three fetuses B19 DNA positive nuclei were occasionally detected within cells labelled by antibody DE-R-11 to desmin (fig 2I), indicating that B19 DNA is not necessarily confined to circulating blood cells within the fetal myocardium. Heart tissue from the remaining cases was so severely autolysed or over-fixed that labelling for desmin was unsuccessful. No obvious differences were seen in the cell populations containing B19 DNA in fetuses of different gestational age, suggesting that the pathogenesis of infection was similar in each case.

\section{Discussion}

In this study parvovirus B19 infection was diagnosed in five out of 23 cases of anatomically normal non-immune fetal hydrops presenting between 1984 and 1989. Using non-isotopic in situ hybridisation, we retrospectively diagnosed B19 infection in a total of 10 out of 37 anatomically normal hydropic fetuses presenting to the John Radcliffe Hospital, Oxford over a 15 year period (see also Porter et al, $1988^{\circ}$ ). Of all cases of nonimmune hydrops presenting over the same period ( $\mathrm{n}=127)$, B19 was thus responsible for about $8 \%$. The clinical and histopathological details of these positive cases have been described elsewhere. ${ }^{20}$

In situ hybridisation with either non-isotopic or radiolabelled probes has been used to diagnose fetal parvovirus infection by several other groups, ${ }^{21-26}$ though the distribution of virus within fetal tissues has not previously been systematically studied using this technique. In the present study false positive signal was detected in three cases using biotinylated probes; a similar problem was encountered by Nascimento et al (1991), ${ }^{25}$ who attributed the artefact to non-specific biotin capture rather than detection of endogenous biotin. We have found the use of digoxigenin as an alternative probe label to be a convenient and simple means of avoiding biotin related artefacts, and believe the use of an internal positive control such as the $\mathrm{Y}$ repeat probe is also important to avoid false negative results due to inadequate proteolytic digestion or technical variation.
Our results on the organ distribution of B19 DNA in the infected fetus are in broad agreement with the results obtained by others using dot-hybridisation, ${ }^{27}$ the polymerase chain reaction, ${ }^{23}$ and electron microscopy on tissue homogenates. ${ }^{27} 28$ In general, viral DNA was most abundant in the liver (the major site of haemopoiesis in the early second trimester), relatively plentiful in the lung, kidney, thymus and heart, and least abundant in the brain and placenta. This suggests that although investigation of the placenta is valuable in many instances, ${ }^{18}$ use of this organ alone for diagnostic purposes may lead to error.

While the importance of detecting varying amounts of viral DNA in different organs using dot-hybridisation techniques is difficult to assess, ${ }^{27}$ the combination of non-isotopic in situ hybridisation for viral nucleic acid with immunohistology for cellular antigens provides a powerful tool for determining exactly where infected cells are located, and which cell types are involved in each organ. The findings of the present study confirm and extend preliminary results obtained using a biotin double label system on tissues from a single case, ${ }^{10}$ and show that the pattern of infection is similar across a range of gestational ages.

Immunolabelling with antibody to glycophorin A confirmed that the classic inclusioncontaining cell was a late erythroid precursor (fig 2A), but many more cells contained B19 DNA than contained obvious viral inclusions, and some of these cells could be labelled by a variety of non-erythroid markers, notably those against mononuclear-phagocytic cell antigens (figs $2 \mathrm{D}$ and $\mathrm{E}$ ), and against the intermediate filament desmin in the heart (fig $2 \mathrm{H})$. Although fetal B19 infection has been clinically associated with neutropenia and thrombocytopenia, ${ }^{29}$ viral DNA was not detected in myeloid cells or megakaryocytes.

The demonstration of intact, B19 positive nuclei within the cytoplasm of numerous mononuclear-phagocytic cells suggests that phagocytosis has an important role in clearing the virus and that lysis of infected erythroid cells is not a universal feature. Sequestration of viral nucleic acid in monocytes is known to play an important part in the persistence and spread of several other viruses including cytomegalovirus and measles, ${ }^{30}$ and further studies are required to determine the exact role of these cells in human parvovirus infection.

In non-autolysed myocardial tissue from three cases positive viral signal could occasionally be clearly shown in cells staining positive for the cytoskeletal filament desmin, confirming earlier findings ${ }^{910}$ and suggesting that the virus has a tropism for certain myocardial cells in the fetus. Coexpression of intermediate filaments is known to occur during early stages of fetal development, ${ }^{31}$ and unequivocal assignment of the parvovirus DNA containing myocardial cells as myocytes will require ultrastructural studies on well preserved material. However, the fact that inflammatory cell infiltrates were also noted on routine histology in these cases $^{20}$ suggests that myocardial damage (either direct or indirect) is a common feature 
of human fetal parvovirus infection. Canine and feline parvovirus infections have been associated with fatal myocarditis, ${ }^{32}$ and there have been reports of myocarditis secondary to B19 infection in an embryo with congenital eye abnormalities, ${ }^{33}$ in a hydropic fetus with only mild anaemia, ${ }^{29}$ in a second hydropic fetus associated with focal myocardial calcification ${ }^{34}$ and in two young children with serological evidence of B19 infection. ${ }^{35}$ No cases of myocarditis in adults infected with B19 have been reported, but, interestingly, chronic congestive cardiac failure caused by fibrous scarring can result from canine parvovirus infection in the neonatal period. ${ }^{37}$ Further studies are indicated to examine the role of B19 in both acute myocarditis and idiopathic cardiomyopathy in man.

We thank Dr S Gould (John Radcliffe Hospital, Oxford; formerly of University College, London) and $\mathrm{Dr} \mathrm{E}$ Gray (Department of Pathology, University Medical Buildings, laboratory (Oxford) generously provided monoclonal antibodies and APAAP reagents. This work was partly funded by the Wellcome Trust. ALM is a Nuffield Medical Research Fellow and Junior Research Fellow of New College, Oxford.

1 Cossart YE, Field AM, Cant B, Widdows D. Parvovirus-like particles in human sera. Lancet 1975;i:72-3.

2 Anderson MJ, Lewis E, Kidd IM, Hall SM, Cohen BJ. An outbreak of erythema infectiosum associated with human outbreak of erythema infectiosum associated

3 Pattison JR, Jones SE, Hodgson J, et al. Parvovirus infection and hypoplastic crisis in sickle cell anaemia. Lancet $1981 ; \mathrm{i}: 664-5$

4 Kurtzman GJ, Ozawa K, Cohen B, Hanson G, Oseas R, Young NS. Chronic bone marrow failure due to persistent B19 parvovirus infection. $N$ Engl $f$ Med 1987; 317:287-94.

5 Brown T, Anand A, Ritchie LD, Clewley JP, Reid TM. Intrauterine parvovirus infection associated with hydrops fetalis. Lancet 1984;ii:1033-4.

6 Public Health Laboratory Service Working Party on Fifth Disease. Prospective study of human parvovirus (B19) Disease. Prospective study of human parvovirus (B19
infection in pregnancy. $\mathrm{Br} \mathrm{Med} \mathcal{f} 1990 ; 300: 1166-70$.

7 Morey AL, O'Neill HJ, Coyle PV, Fleming KA. Immunohistological detection of parvovirus $\mathrm{B} 19$ in formalin-fixed, paraffin-embedded tissues. $\mathcal{F}$ Pathol 1992;166:105-8.

8 Porter HJ, Khong TY, Evans MF, Chan VT, Fleming KA. Parvovirus as a cause of hydrops fetalis: detection by in situ DNA hybridisation. $\mathcal{f}$ Clin Pathol 1988;41:381-3.

9 Porter HJ, Quantrill AM, Fleming KA. B19 parvovirus infection of myocardial cells. Lancet 1988;i:535-6.

10 Porter HJ, Heryet A, Quantrill AM, Fleming KA. Combined non-isotopic in-situ hybridization and immunohistochemistry on routine clinical material: identification of cell type infected by human parvovirus and demon of cell type infected by human parvovirus and demonstraPathol 1990;43:129-32.

11 Burton PA. Intranuclear inclusions in marrow of hydropic fetus due to parvovirus infection. Lancet 1986 ;ii: 1155 .

12 Burns J, Graham AK, Frank C, Fleming KA, Evans MF, McGee J. Detection of low copy human papilloma virus DNA and mRNA in routine paraffin sections of cervix by non-isotopic in situ hybridisation. $f$ Clin Pathol 1987;40:858-64.

13 Fleming KA, Evans M, Ryley KC, Franklin D, LovellBadge RH, Morey AL. Optimisation of non-isotopic in situ hybridization on formalin-fixed paraffin-embedded material using digoxigenin labelled probes and transgenic tissues. F Pathol 1992;167:9 17.

14 Cotmore SF, McKie VC, Anderson LJ, Astell CR, Tattersall $T$. Identification of the major structural and nonstructural proteins encoded by human parvovirus B19 and mapping of their genes by procaryotic expression of isolated genomic fragments. 7 Virol 1986;60:548-57.

15 Cooke HJ, Schmidtke T, Gosden JR. Characterisation of human $\mathrm{Y}$ chromosome repeated sequence and related sequences in higher primates. Chromosoma 1982;87: 491-502.

16 Cordell JL, Fallini B, Erber WN, et al. Immunoenzymatic labelling of monoclonal antibodies using immune complexes of alkaline phosphatase and monoclonal antialkaline phosphatase (APAAP complexes). 7 Histochem Cytochem 1984;32:219-29.

17 Greywoode GIN, McCarthy SP, McGee JO'D. Labelling of cells of the mononuclear phagocyte system in routinely processed archival biopsy specimens with monoclonal processed archival biopsy specimens with mo
antibody EBM $/ 1$. F Clin Pathol 1990;43:992-6.

18 Burton PA, Caul EO. Fetal cell tropism of human parvovirus B19. Lancet 1988;i:767.

19 Stross P, Warnke RA, Flavell DJ, et al. Molecule detected in formalin fixed tissue by antibodies MT1, DF-T1 and L60 (Leu-22) corresponds to CD43 antigen. 7 Clin Pathol 1989;42:953-61.

20 Morey AL, Keeling JW, Porter HJ, Fleming KA. Clinical and histopathological features of parvovirus B19 infection in the human fetus. Br $\mathcal{f}$ Obstet Gynaecol (in press)

21 Anderson MJ, Khousam MN, Maxwell DJ, Gould SJ Happerfield LC, Smith WJ. Human parvovirus B19 and Happerfield LC, Smith WJ. Human

22 Franciosi RA, Tattersall P. Fetal infection with human parvovirus B19. Hum Pathol 1988;19:489-91.

23 Salimans MMM, van de Rijke FM, Raap AK, van ElsackerNiele AMW. Detection of parvovirus B19 DNA in fetal tissues by in situ hybridisation and polymerase chai reaction. $\mathcal{F}$ Clin Pathol 1989;42:525-30.

24 Hassam S, Tratschin JD, Siegl G, Heitz PhU. In situ hybridization for the detection of human parvovirus B19 nucleic acid sequences in paraffin-embedded specimen. Virchows Arch (Cell Pathol) 1990;59:257-61.

25 Nascimento JP, Hallam NF, Mori J, et al. Detection of B19 parvovirus in human fetal tissues by in situ hybridization parvovirus in human fetal tissu
7 Med Virol 1991;33:77-82.

26 Schwarz TF, Nerlich A, Hottentrager B, et al. Parvovirus B19 infection of the fetus. Histology and in situ hybridB19 infection of the fetus. Histology and
ization. Am $\mathrm{f}$ Clin Pathol 1991;96:121-6.

27 Clewley JP, Cohen BJ, Field AM. Detection of parvovirus B 19 DNA, antigen, and particles in the human fetus f Med Virol 1987;23:367-76.

28 Bond PR, Caul EO, Usher J, Cohen BJ, Clewley JP, Field AM. Intrauterine infection with human parvovirus. Lancet 1986; i:448-9.

29 Naides SJ, Weiner CP. Antenatal diagnosis and palliative treatment of non-immune hydrops fetalis secondary to fetal parvovirus B19 infection. Prenat Diagn 1989; 9:105-14.

30 Whitton LJ, Oldstone MBA Virus-induced immune response interactions. Principles of Immunity and Immuresponse interactions. Principles of Immunity and Immu-
nopathology. In: Fields BN, Knipe DM, et al., eds. nopathology. In: Fields BN, Knipe DM, et al., eds.
Virology (2nd edn). New York: Raven Press, Virology (2nd

31 van Muijen GN, Ruiter DJ, Warnaar SO. Coexpression of intermediate filament polypeptides in human fetal and adult tissues. Lab Invest 1987;57:359-69.

32 Siegl G. Biology and pathogenicity of autonomous parvoviruses. In: Berns KI, ed. The parvoviruses. New York: Plenum Press, 1984:297-362.

33 Weiland HT, Vermey-Keers C, Salimans MM, Fleuren GJ, Verwey RA, Anderson MJ. Parvovirus B19 associated with fetal abnormality. Lancet 1987; i:682-3.

34 Katz VL, Chescheir NC, Bethea M. Hydrops fetalis from B19 parvovirus infection. $\mathcal{F}$ Perinatol 1990;10:366-8.

35 Knisely AS, O'Shea PA, Anderson LJ, Gary GW. Parvovirus B19 infection, myocarditis, and death in a 3-year-old boy. Pediatr Pathol Abstr 1988;8:665.

36 Saint-Martin J, Choulot JJ, Bonnaud E, Morinet F. Myocarditis caused by parvovirus. $\mathcal{f}$ Pediatrics 1990 116:1007.

37 Lenghaus C, Studdert MJ. Acute and chronic viral myocarditis. Acute diffuse nonsuppurative myocarditis and residual myocardial scarring following infection with canine parvovirus. Am 7 Pathol 1984;115:316-9. 